\title{
Factors Contributing to Collaborative Game-Based Learning (CGBL) Effectiveness
}

\author{
Aryanti Amran ${ }^{1}$, Habibah Ab Jalil ${ }^{1}$, Mokhtar Muhamad ${ }^{1}$, Nurul Amelina Nasharuddin ${ }^{2}$ \\ ${ }^{1}$ Faculty of Educational Studies, Universiti Putra Malaysia, Serdang, Selangor, Malaysia \\ ${ }^{2}$ Faculty of Computer Science and Information Technology, Universiti Putra Malaysia, Serdang, Selangor, \\ Malaysia \\ Correspondence: Habibah Ab Jalil, Faculty of Educational Studies, Universiti Putra Malaysia, 43400 UPM Serdang, \\ Selangor, Malaysia. Tel: 603-9769-8210. E-mail: habibahjalil@upm.edu.my
}

Received: September 3, $2021 \quad$ Accepted: September 28, $2021 \quad$ Online Published: October 14, 2021

doi:10.5539/ass.v17n11p1 URL: https://doi.org/10.5539/ass.v17n11p1

\begin{abstract}
In facing the Covid-19 pandemic, the teaching and learning landscape in Malaysian schools has also changed accordingly. The Ministry of Education has introduced Teaching and Learning at Home to take over the previous methods. Conventional teaching methods are unfitting during the 'new norm'. Therefore, teachers need to diversify their instructional strategies and search for various resources in the digital environment - learning in this mode should create a fun digital learning environment. Digital Game-based Learning (DGBL) is a teaching aid that is capable of promoting enjoyment in learning. This article focused on DGBL as a learning method in a collaborative environment called Collaborative Game-based Learning (CGBL). There is a shortage of insight on the factors that support DGBL's efficiency in the digital environment, specifically in CGBL in educational settings. This article employed a systematic Thematic Review (TR) approach to synthesise the literature published from 2016 until 2021 on CGBL in the digital environment. A keyword search was conducted, followed by a filtering process using inclusion criteria from the Scopus, Lens, and Mendeley databases. The author identified 65 peer-reviewed journal papers. Only 34 articles were used to be reviewed after the inclusion and exclusion processes. A TR of these articles identified 95 initial codes, later grouped into 32 codes, and created ten categories from three themes. From the TR results, it is found that the factors contributing to CGBL effectiveness are learning environment, learning motivation and learning strategies. This work provides insight on various parties in considering the implementation of CGBL in Teaching and Learning at Home as one of the appropriate alternative resources and methods.
\end{abstract}

Keywords: Collaborative game-based learning (CGBL), collaborative digital learning, digital learning, new norm learning, self-directed learning

\section{Introduction}

The world moves with great uncertainty, complexity, and doubt in the face of the global megatrend or the VUCA world (volatility, uncertainty, complexity, and ambiguity). The Covid-19 pandemic has affected students' learning all over the world, including Malaysia. As a result, the learning session had to continue from home from March 2020 onwards as all schools were closed and students are required to learn from home. The Covid-19 pandemic has caused many changes, especially in education, and therefore, teachers and students are expected to be more prepared to face digital learning (Wibawa, 2018). However, how far can digital learning be implemented effectively? Indeed, a different set of efficacy is needed as digital learning differs from the face-to-face learning environment. During the Movement Control Order (MCO), digital learning is the only possible method available and therefore, teachers need to be better prepared and plan their teaching materials that are suitable to the new environment. They must provide innovative teaching approaches and materials to deliver the teaching and learning process to students effectively. In addition, planning the teaching and learning method in this mode should consider fun environment conditions that are more easily done in the physical environment.

Mat Dawi et al. (2016) found that the distance between educators and students is not a barrier for implementing the learning process. While there has been an ongoing call for integrating technology in education for decades, the current pandemic has increased the need to include emerging technologies in instruction although there has been an ongoing call for integrating technology in education. As institutions struggle to come up with innovative 
teaching and course design approaches that can boost the learners' retention and motivation in emotionally trying times (Bahrom, 2013; Sutton \& Jorge, 2020; Huang et al., 2020), the conduct of teaching and learning processes should be creatively maintained and offer innovative infusions during interactive sessions with students.

Online learning has been widely used to ensure the success of the Teaching and Learning at Home process during the Movement Control Order (MCO). The Home Learning approach means moving the learning process from the classroom to home (Hussin, 2017). Zhou and Li (2020) asserted that online learning selection should consider teachers' benefits as well. Digital learning is teaching and learning delivered through digital technology (Agatha \& Muhamad, 2016). This learning mode comprises words, video, animation, audio, and visual graphics. It is also equipped with group learning facilities with the help of online instructors. Digital learning is carried out regardless of the distance and number of members accessing it. Learning occurs when students and teachers and teaching and learning resources are separated by space and time due to the inability to carry out classes conventionally.

Digital Game-based Learning (DGBL) is one of the digital learning approaches that is getting more attention nowadays (Al-Emran, 2020; Naciri et al., 2020). During pandemic times, the virtual presence might be a good alternative, as it reinforces the connection of virtual learning spaces without physical interactions (Al-Emran, 2020). DGBL includes a method of learning that can effectively increase learning using game playing (Campos, 2018). Using this approach would make it easier for students to use the game as a learning approach. As an input subject content, several observations indicated that children or students could absorb their studies or information about $80 \%$, and it can be done through a simulated approach (Prasetyo \& Sutopo, 2018). DGBL describes an approach in teaching where students discover related aspects of the game in a design game. DGBL is a centralised educational study that uses electronic games for educational uses. The DGBL process leverages the game on the computer or gadget as a medium that delivers learning, enhances understanding and knowledge capabilities, and evaluates the discipline of knowledge. These opinions are supported by Wouters and Van Oostendorp (2013), defining digital games for education as a tool on a game approach aimed at supporting, enhancing teaching, learning, delivering, evaluation, and assessment. Prensky (2007) expressed DGBL as computer education and gaming content integration. As opposed to the traditional methods, DGBL has made it possible to combine computer and video games with different educational content to obtain better results. Digital games which require a deeper level of thought are also found to involve mental development. Besides, it provides students with fun learning without compromising the importance of learning concepts.

The significance of integrating computer games as an integral part of the students' careers and lifelong learning skills can be seen through the recent trend in the professional industry. Bughin et al. (2018) recommended ensuring that potential employees are highly trained in new technologies, while also developing interdisciplinary skills to improve critical thinking. In the future, the greatest challenge for people will be to use such a wide variety of knowledge and expertise in looking for new solutions manipulated by emerging technologies (Islam, 2017). The Paradigm of Education 4.0 empowers students to establish their learning style and speed. According to Bartolomé et al. (2018), personalisation and versatility are essential characteristics of Education 4.0. Adaptive learning systems play a crucial role in the Education 4.0 model (Cope \& Kalantzis, 2010). Technology is used in the adaptive learning model to speed up learning according to each student's different needs. Besides, Murray and Pérez (2015) found that adaptive systems benefit other facets of the educational process, such as motivation and interaction with the students. Games are now part of a professional training programme in specialised careers such as engineering, military, and medical. Before this, students engaged in games just for leisure and entertainment (Prensky, 2007). For example, soldiers undergoing combat training will now be equipped with a realistic 3D video game; simulation aircraft pilots who have long utilised computer simulations during their preparation; and medical doctors can now perform surgical operations using computer game models and improve electronic medical devices.

As Gunter et al. (2008), an educational game's effectiveness is generally dependent on improving learning to inspire social connections rather than the force of knowledge acquisition. These conditions suggest that, while most people trust DGBL's potential to improve learning motivation, its ability to improve knowledge acquisition effectiveness is questionable. As a result, it is critical to investigate the riddle of DGBL learning effectiveness. A practical way is to understand the factors influencing learners' knowledge acquisition effectiveness in DGBL. According to Mitchell and Savill-Smith (2004), students' distraction generated by game play is a critical component affecting their learning efficacy in DGBL. Nevertheless, this research issue has yet to be studied (Keskitalo et al., 2016).

These show that digital games can become a medium for professional skills training. Thus, incorporating computer games in school education can introduce and familiarise students with their later professional lives. 
The combination of computer games in the education system is a strenuous effort of developed countries like the United Kingdom and the United States of America (USA). In an effort to implement computer games in the classroom, sometimes, a specific DGBL curriculum is built. This transformation of the education system was recently achieved kudos to extensive research and development efforts by educational researchers, educators, and developers of educational games.

Although many studies on DGBL have been conducted, very few studies focus on collaborative learning in DGBL being a more practical approach. Therefore, this article will perform a thematic analysis to synthesise literature from 2016 to 2021 on CGBL systematic Thematic Review (TR) to explore factors that contribute to the effectiveness of CGBL in teaching and learning discussed in the publications through the following research question:

\section{RQ: What factors contribute to Collaborative Game-based Learning (CGBL) effectiveness in literature} from 2016 to 2021?

The paper ends with some final considerations and future needs. The main contribution of this paper is to indicate the factors that can be considered a guideline for teachers to understand better why they need alternative approaches to apply Collaborative Game-based Learning in teaching and learning in the Covid-19 pandemic era. It is also a reference and guide to the Ministry of Education Malaysia to make this method one of the alternative learning environments that is fun and very effective to students regardless of formal and informal learning.

\section{Materials and Methodology}

Thematic Review using ATLAS.ti 8 as the tool introduced by Zairul (2020), was implemented because the method of this study applied the thematic analysis procedure in a literature review. Thematic analysis is used to identify pattern and construct themes over thorough reading on the subject (Clarke \& Braun, 2013). The following step is to identify the pattern and construct categories to understand the factors that contribute to the effectiveness of CGBL in the education system. This paper's creeds are to analyse and evaluate the results in order to make recommendations for future research. The selection of literature was performed according to several selection criteria: 1) publication from 2016 to 2021;2) has at least keyword(s) relative to the topic; and 3) focuses on Collaborative Digital Game-based Learning.

Table 1. Search strings from Scopus, Lens.org and Mendeley

\begin{tabular}{|c|c|c|}
\hline \multirow[b]{2}{*}{ Scopus } & $\begin{array}{l}\text { TITLE-ABS-KEY ( "collaborative" AND ( "digital game based learning" OR "game-based } \\
\text { learning" OR dgbl OR gbl ) AND ("effectiveness" OR "success*") ) }\end{array}$ & $\begin{array}{l}80 \\
\text { results }\end{array}$ \\
\hline & $\begin{array}{l}\text { TITLE-ABS-KEY ( ( "Collaborative Game-based Learning" OR cgbl OR ( ( "digital game based } \\
\text { learning" OR dgbl ) AND ( collaborative ) ) ) AND ( effective* OR success* ) AND ( factor* OR } \\
\text { element* OR component*) ) }\end{array}$ & $\begin{array}{l}10 \\
\text { results }\end{array}$ \\
\hline \multirow[b]{2}{*}{ Mendeley } & $\begin{array}{l}\text { title:collaborative AND ( "digital game based learning" OR "game based learning" OR DGBL OR } \\
\text { GBL OR CGBL) AND ("effectiveness" OR "success*") }\end{array}$ & $\begin{array}{l}35 \\
\text { results }\end{array}$ \\
\hline & $\begin{array}{l}\text { title:collaborative AND ( "digital game based learning" OR "game based learning" OR DGBL OR } \\
\text { GBL) AND ("effectiveness" OR "success*") NOT proceeding NOT conference NOT reports AND } \\
\text { year:[2016 TO 2021] }\end{array}$ & 6 results \\
\hline \multirow{3}{*}{ Lens } & $\begin{array}{l}\text { Scholarly Works }(101)=(\text { "Collaborative Game-based Learning" OR cgbl OR ( ( "digital game } \\
\text { based learning" OR dgbl ) AND ( collaborative })) \text { ) AND ( effective* OR success*) AND ( factor* } \\
\text { OR element* OR component*) }\end{array}$ & $\begin{array}{l}101 \\
\text { results }\end{array}$ \\
\hline & $\begin{array}{l}\text { Scholarly Works }(24)=(\text { "Collaborative Game-based Learning" OR cgbl OR ( ( "digital game } \\
\text { based learning" OR dgbl ) AND ( collaborative ) ) ) AND ( effective* OR success* ) AND ( factor* } \\
\text { OR element* OR component*) }\end{array}$ & \multirow[t]{2}{*}{$\begin{array}{c}24 \\
\text { results }\end{array}$} \\
\hline & Filters: Year Published $=(2016-2021)$ & \\
\hline
\end{tabular}

A comprehensive review of research articles was conducted in the first step to determine the existing status of academic insight regarding collaboration in the DGBL. If accessible, the published articles were extracted from the Scopus database using the keyword TITLE-ABS-KEY ( "collaborative" AND ( "digital game-based learning" OR "game-based learning" OR dgbl OR gbl ) AND ( "effectiveness" OR "success*") ) AND ( LIMIT-TO ( PUBSTAGE, "final" ) ) AND ( LIMIT-TO ( DOCTYPE, "ar" ) ) AND ( LIMIT-TO ( PUBYEAR, 2021 ) OR LIMIT-TO ( PUBYEAR , 2020 ) OR LIMIT-TO ( PUBYEAR , 2019 ) OR LIMIT-TO ( PUBYEAR , 2018 ) OR LIMIT-TO ( PUBYEAR , 2016 ) AND ( LIMIT-TO ( LANGUAGE, "English" ) ) ). The Mendeley database was also used to extract Elsevier publications using the keyword title: collaborative AND ("digital game-based learning" OR "game-based learning" OR DGBL OR GBL) AND ("effectiveness" OR "success*”) NOT 
proceeding NOT conference NOT reports AND year: [2016 TO 2021]. In addition, searches on Lens.Org were done by using this search string: Scholarly Works (24) = ("Collaborative Game-based Learning" OR cgbl OR ( ( "digital game-based learning" OR dgbl ) AND ( collaborative ) ) ) AND ( effective* OR success*) AND ( factor* OR element* OR component*) Filters: Year Published $=(2016-2021)$.

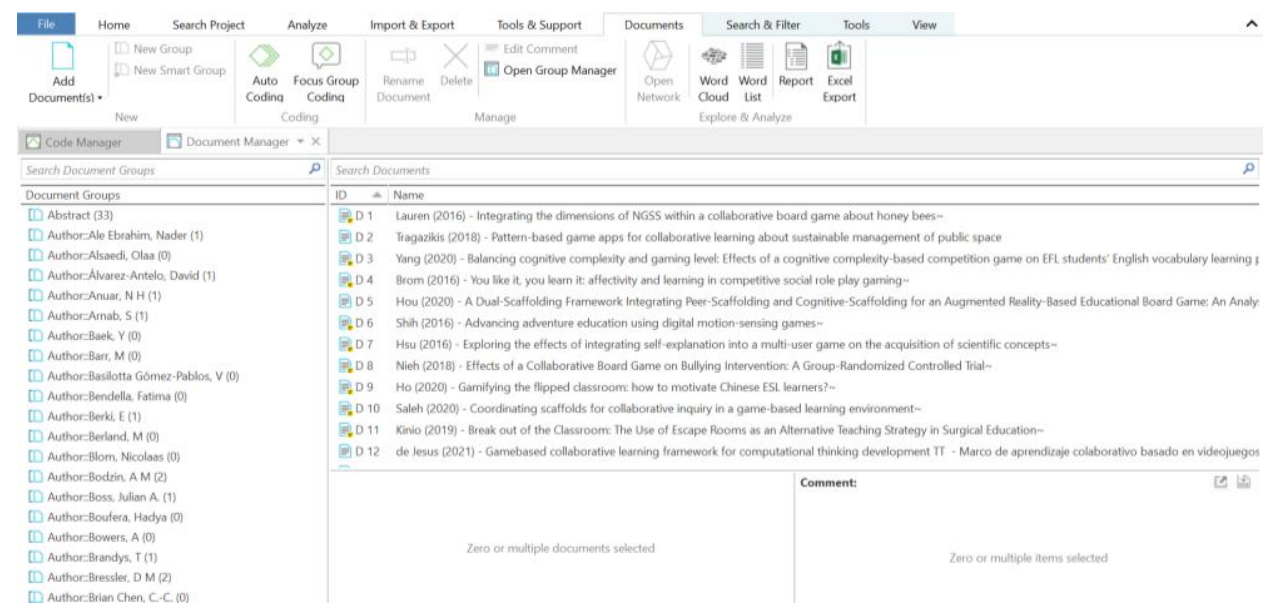

Figure 1. Documents extracted from Mendeley database

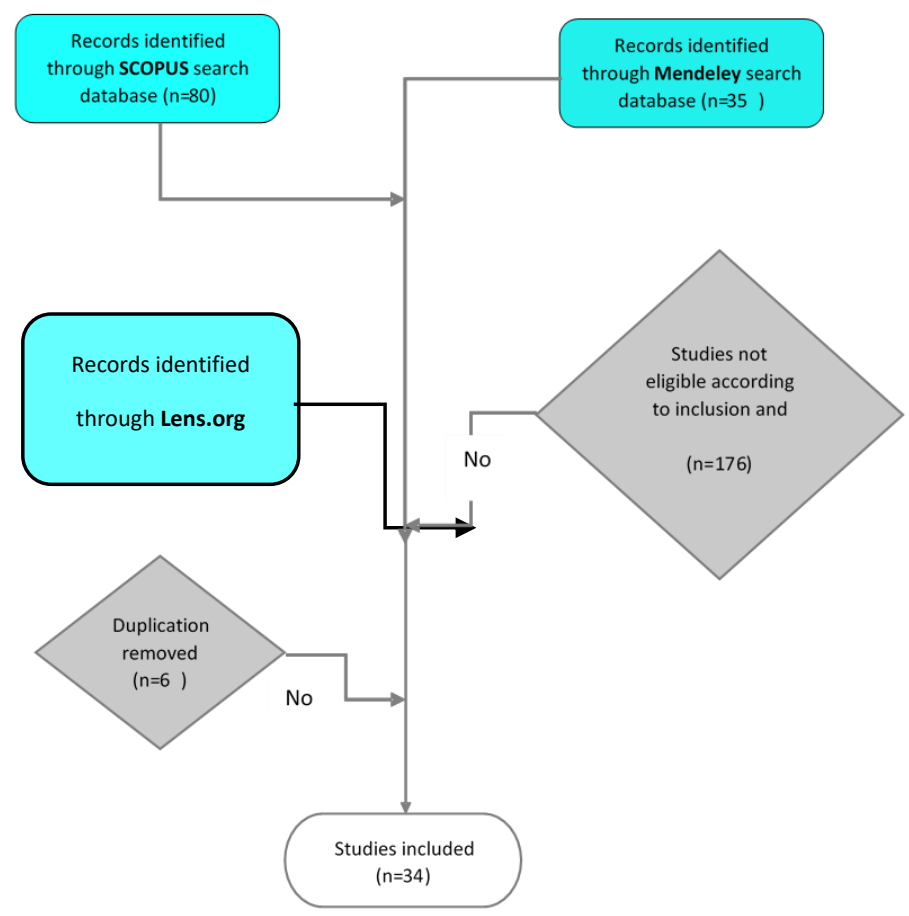

Figure 2. Inclusion and exclusion criteria

These search findings resulted in about 216 publications considering the results from three databases (Table 1). This review was limited to peer-reviewed journals and theses, and after some duplications were found, 176 publications were removed. As a next step, articles have been considered for review that was published during the last five years (2016 until 2021 inclusively). Articles have been regarded as irrelevant if the association with DGBL in education, i.e. an DGBL perceived as medical or computer science, has been removed. Due to the major share of articles focusing on DGBL in the collaboration setting. Next, all 40 metadata were transferred to ATLAS.ti 8 and created as primary documents. After the final screening on each document, three articles were irrelevant to education and were removed from the list. Following the filtering process, another 6 of the 40 articles were removed due to their premature results, duplicates, and anecdotes. Moreover, they did not discuss issues in education. The articles were uploaded in the ATLAS.ti 8 as primary documents, and then each paper was grouped as follows: 1) author; 2) issue number; 3) periodical; 4) publisher; 5) volume; and 6) year of 
publication (Figure 1). The articles were analysed according to the year of publication and the discussion pattern.

Therefore, the final number of papers to be reviewed was 34 papers (see Figure 2). Word cloud was generated from the 34 articles reviewed (Figure 3). Several categories in the code group were started automatically based on information given in Mendeley. (Figure 4). The classification in ATLAS.ti 8 made the sorting much more manageable and systematic. In the first round of coding, 95 initial codes were produced. Later, the codes were grouped into categories and several themes. In answering the research question on "What factors contribute to Collaborative Game-based Learning (CGBL) effectiveness in literature from 2016 to 2021?", this contributed to the final three themes. The findings of this review are divided into quantitative and qualitative findings.

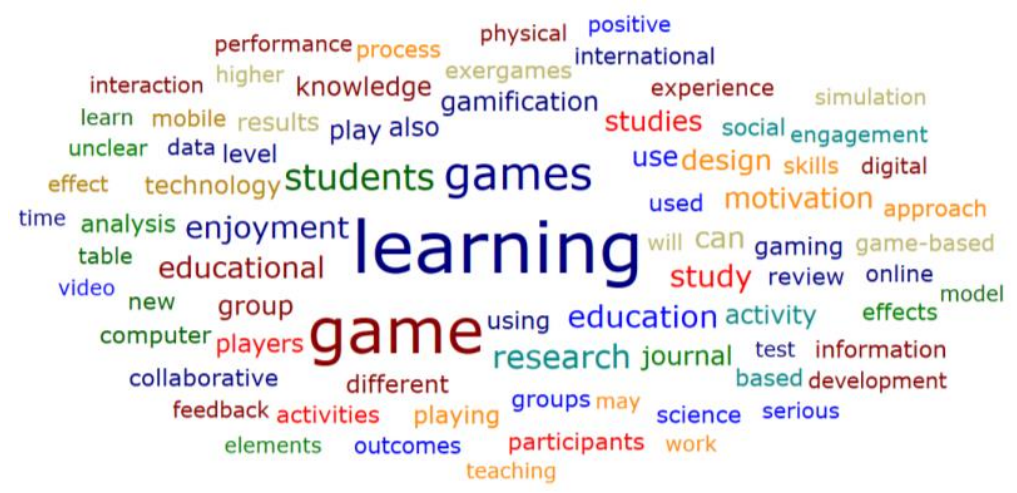

Figure 3. Word cloud generated from 34 articles

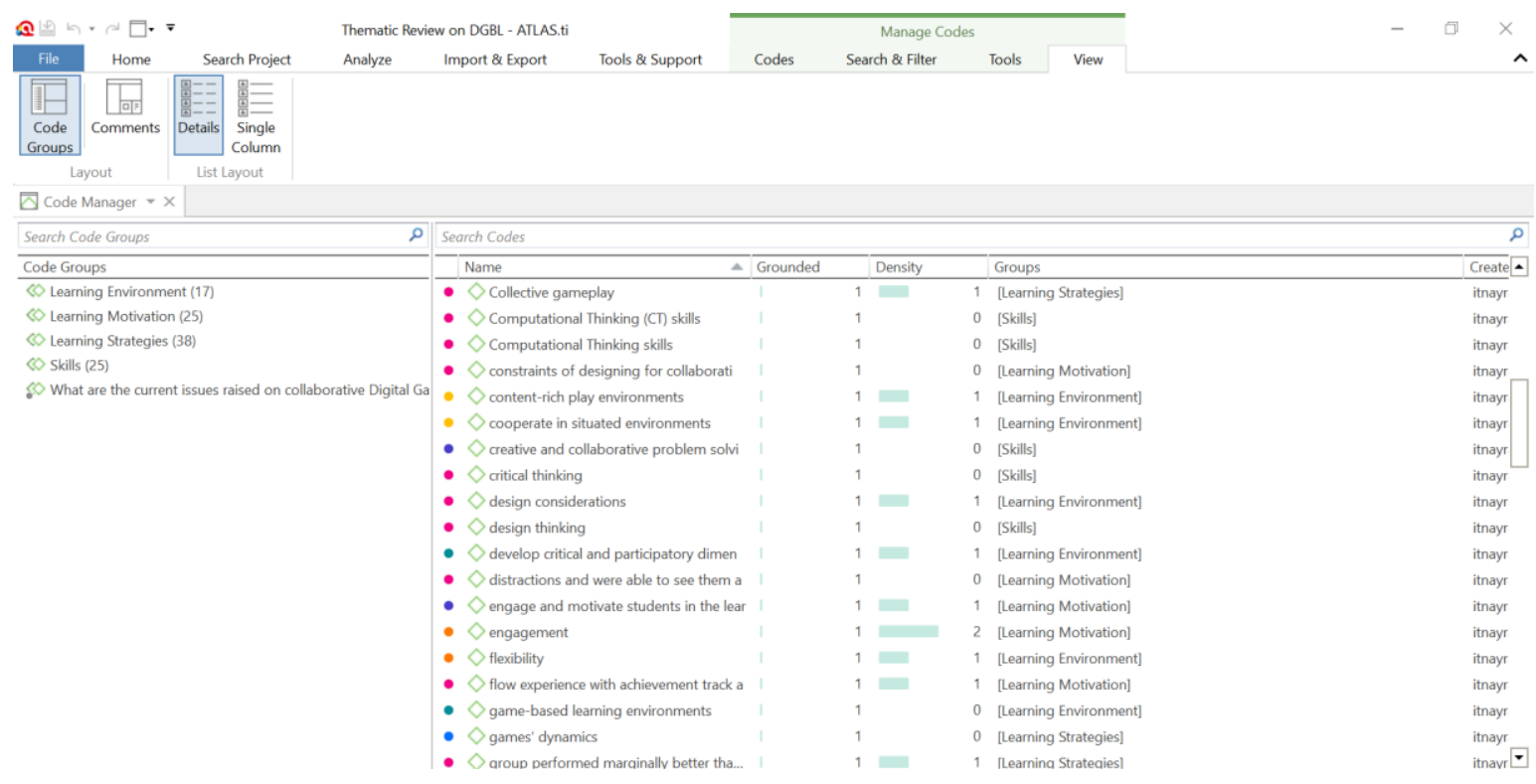

Figure 4. The code group established from Mendeley metadata

\section{Results and Discussions}

The data are presented in two forms, quantitatively and qualitatively. The quantitative data will explain descriptively about the data obtained and include more on numbers. In contrast, the qualitative data will display the themes that appear from the analysis results in each article. At the end of this section, some of the highlights will be discussed to suggest for the subsequent study.

\subsection{Quantitative Data}

Database queries were static and the use of the phrase "DGBL" OR "Digital Game-based Learning" was scarce in only research articles to identify the factors. Though the paper was meant for social studies, the journals recorded that the articles were published in various fields. DGBL was afterwards carried out by a critical review of the findings in light of the significant associated pedagogies exercised as alternative learning. Table 2 and Figure 5 below show that the trend of publishing increased from year to year. In 2017, few publications 
highlighted the idea of CGBL in their papers. However, when this article was written, 2017 and 2018 recorded only nine publications, which was probably due to some articles that were still in progress, or the pattern of this topic was not popular. In 2019 and 2020, there was a sudden increase in the number of articles on this topic, perhaps because the pandemic that hit the world had opened reviewers' eyes to research other methods of applying teaching and learning at home. This article noticed that most journals involved were from other irrelevant branches of social sciences, such as business and psychology.

Table 2. Paper breakdown according to the authors and years

\begin{tabular}{|c|c|c|c|c|c|c|}
\hline Author(s) & 2016 & 2017 & 2018 & 2019 & 2020 & 2021 \\
\hline Lauren, Lutz, Wallon, and Hug & I & & & & & \\
\hline Tragazikis and Gouscos, & & & / & & & \\
\hline Yang, Chang, Hwang, and Zou & & & & & l & \\
\hline Brom, Šisler, Slussareff, Selmbacherová, and Hlávka & I & & & & & \\
\hline Hou and Keng & & & & & l & \\
\hline Shih and Hsu & I & & & & & \\
\hline Hsu, Tsai, and Wang & I & & & & & \\
\hline Nieh and $\mathrm{Wu}$ & & & / & & & \\
\hline Но & & & & & l & \\
\hline A Saleh et al. & & & & & l & \\
\hline Kinio, Dufresne, Brandys, and Jetty & & & & I & & \\
\hline de Jesus and Silveira & & & & & & I \\
\hline Hoyos, Sigüenza, Capellán-Pérez, Campos, and Álvarez-Antelo & & & & l & & \\
\hline Chu, Wang, and Wang & & & & l & & \\
\hline Çelik & & & & & l & \\
\hline Cheng, Wang, Cheng, and Chen & & & & l & & \\
\hline Martin and Martinez & I & & & & & \\
\hline Romero et al. & & & & I & & \\
\hline Bressler, Bodzin, and Tutwiler & & & & l & & \\
\hline $\mathrm{Li}$ & & & / & & & \\
\hline Magno De Jesus and Frango Silveira & & & & & l & \\
\hline B. Davis, Tu, Georgen, Danish, and Enyedy & & & & l & & \\
\hline Anuar, Mohamad, and Minoi & & & & & I & \\
\hline K. Davis, Boss, and Meas & & & I & & & \\
\hline Asmalina Saleh et al. & & & & l & & \\
\hline Bressler, Bodzin, Eagan, and Tabatabai & & & & l & & \\
\hline Czerwinski, Milosz, Karczmarczyk, Kutera, and Najda & & & / & & & \\
\hline Sousa and Costa & & & l & & & \\
\hline Hussein, Ow, Cheong, Thong, and Ale Ebrahim & & & & l & & \\
\hline Mystakidis and Berki & & & / & & & \\
\hline Turchi, Fogli, and Malizia & & & & / & & \\
\hline Ting, Lam, and Shroff & & & & l & & \\
\hline Hung, Lin, Huang, Yu, and Sun & & I & & & & \\
\hline Emblen-Perry & & & I & & & \\
\hline
\end{tabular}




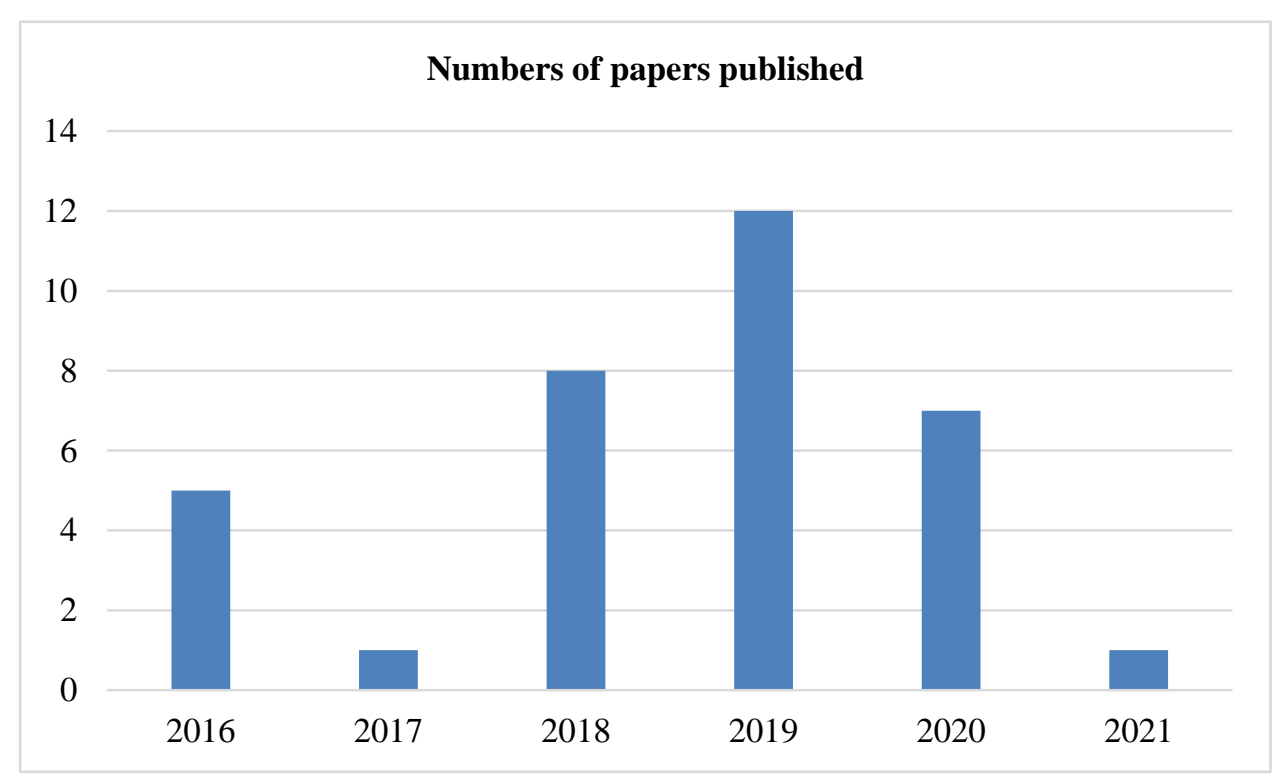

Figure 5. Numbers of the paper published from 2016 to 2021

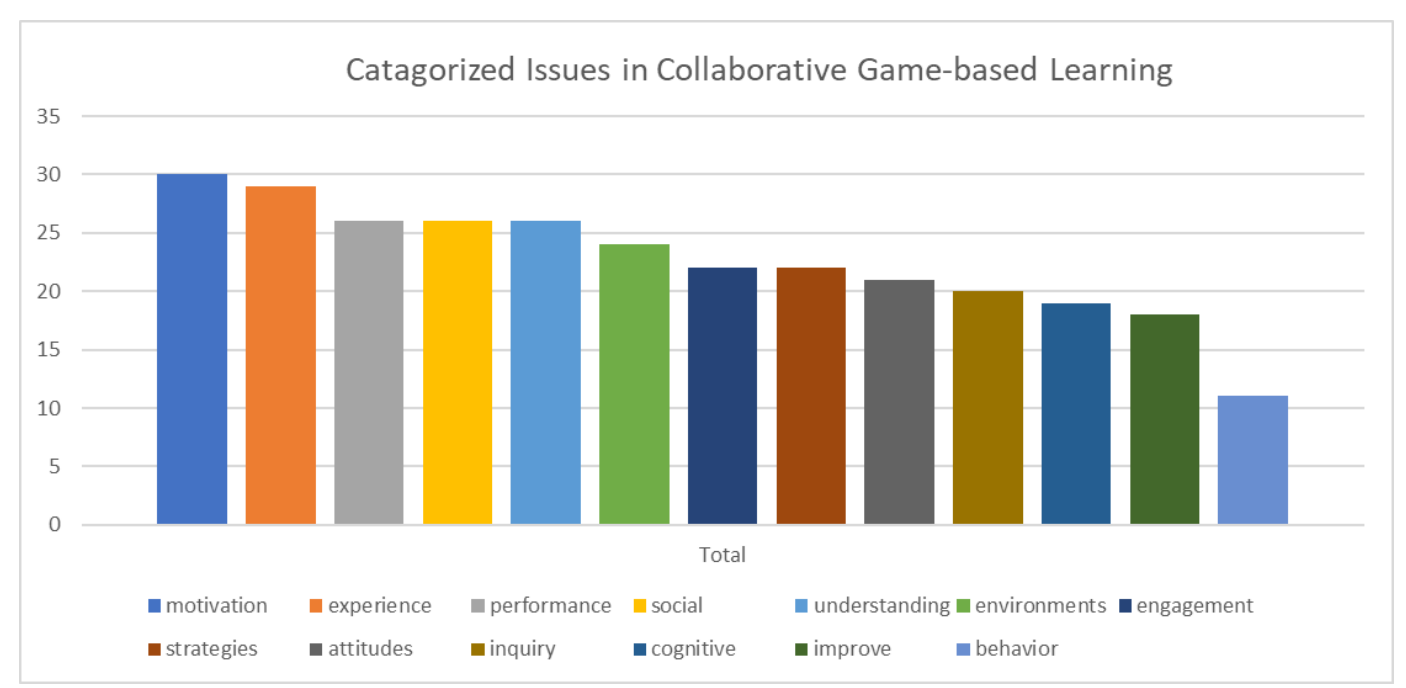

Figure 6. Initial Categorized of issues discussed in the literature

Three main themes are resulting from quotation, and categories scrutiny and scrutiny produced. The themes in examining the effectiveness factors in CGBL are Learning Environment, Learning Motivation, and Learning Strategies. Table 3 shows the breakdown of the publication paper according to the theme produced.

Table 3. Paper breakdown according to the themes generated

\begin{tabular}{cccc}
\hline Articles & Learning Environment & Learning Motivation & Learning Strategies \\
\hline (Lauren, Lutz, Wallon, and Hug, 2016) & $/$ & - & - \\
(Tragazikis and Gouscos, 2018) & $/$ & $/$ & - \\
$($ Ahmad, 2017) & - & - & $/$ \\
$($ Brom et al., 2016) & - & $/$ & $/$ \\
$($ Hou and Keng, 2020) & - & $/$ & $/$ \\
$($ Shih and Hsu, 2016) & $/$ & $/$ & - \\
$($ Hsu et al., 2016) & - & $/$ \\
$($ Nieh and Wu, 2018) & - & $/$ & $/$ \\
(Ho, 2020) & - &
\end{tabular}


(A Saleh et al., 2020)

(Kinio et al., 2019)

(de Jesus and Silveira, 2021)

(Hoyos et al., 2019)

(Chu et al., 2019)

(Çelik, 2020)

(Cheng et al., 2019)

(Martin and Martinez, 2016)

(Romero et al., 2019)

(Bressler, Bodzin, and Tutwiler, 2019)

$$
\text { (Li, 2018) }
$$

(Magno De Jesus and Frango Silveira, 2020)

(B. Davis et al., 2019)

(Anuar et al., 2020)

(K. Davis et al., 2018)

(Asmalina Saleh et al., 2019)

(Bressler, Bodzin, Eagan, et al., 2019)

(Czerwinski et al., 2018)

(Sousa \& Costa, 2018)

(Hussein et al., 2019)

(Mystakidis and Berki, 2018)

(Turchi et al., 2019)

(Ting et al., 2019)

(Hung et al., 2017)

(Emblen-Perry, 2018)

Factors contribute to Collaborative Game-based Learning (CGBL) effectiveness in literature from 2016 to 2021

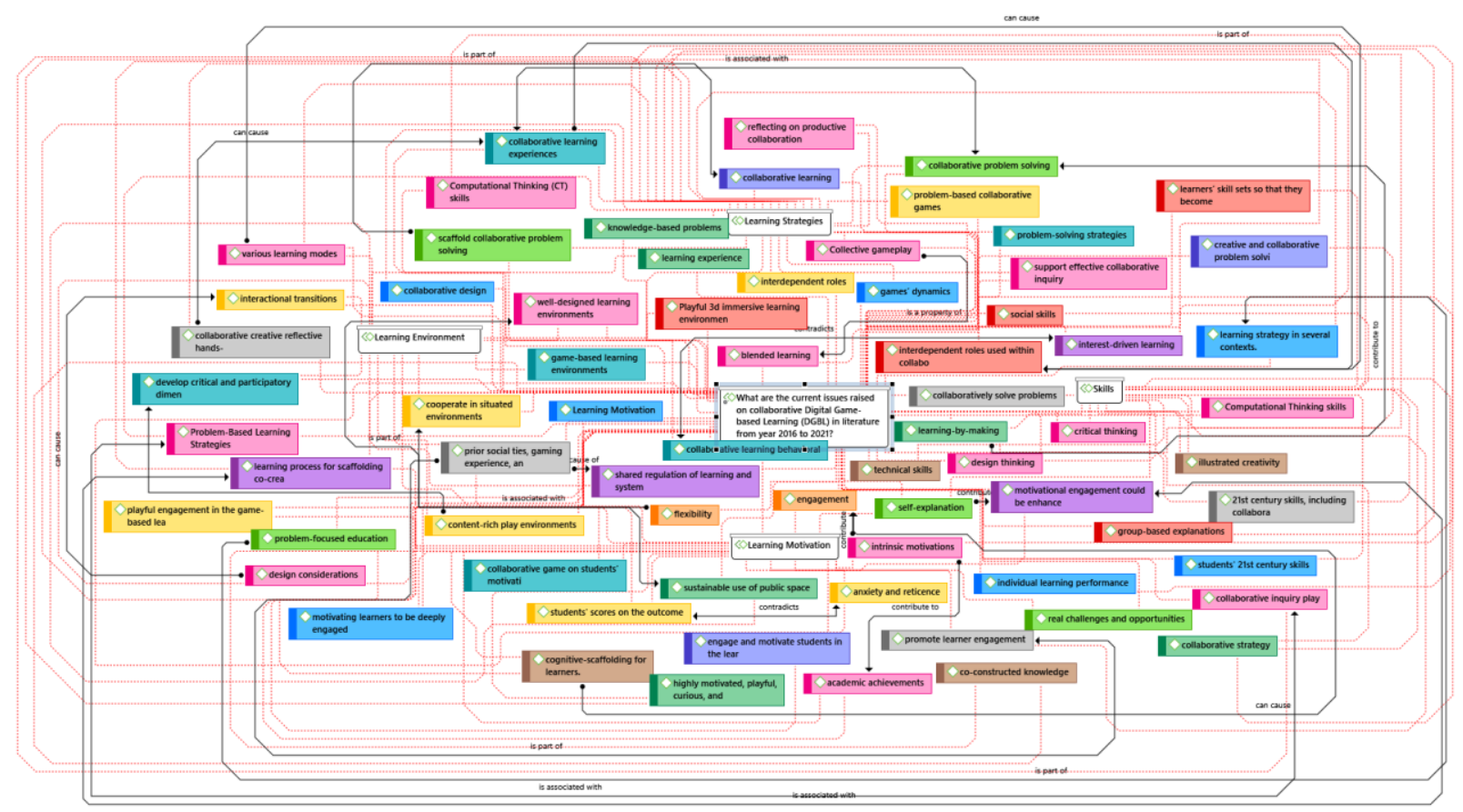

Figure 7. Overall network and how the themes answering the research questions

All the category scrutiny was conducted and there were three main themes that were derived from the research 
question. Figure 6 illustrates the overall network that answers the question of the study, "What factors contribute to CGBL effectiveness in literature from 2016 to 2021?"

\subsection{Qualitative Data}

In this section, the qualitative results are discussed through the themes generated from the research question. Figure 8 is a concept map of the entire findings that refers to each resulting theme and sub-theme. There are three themes derived from the qualitative analysis of this study, namely learning environment, learning motivation, and learning strategies. The relevance of each of these themes is shown in the description in the following sub-section.

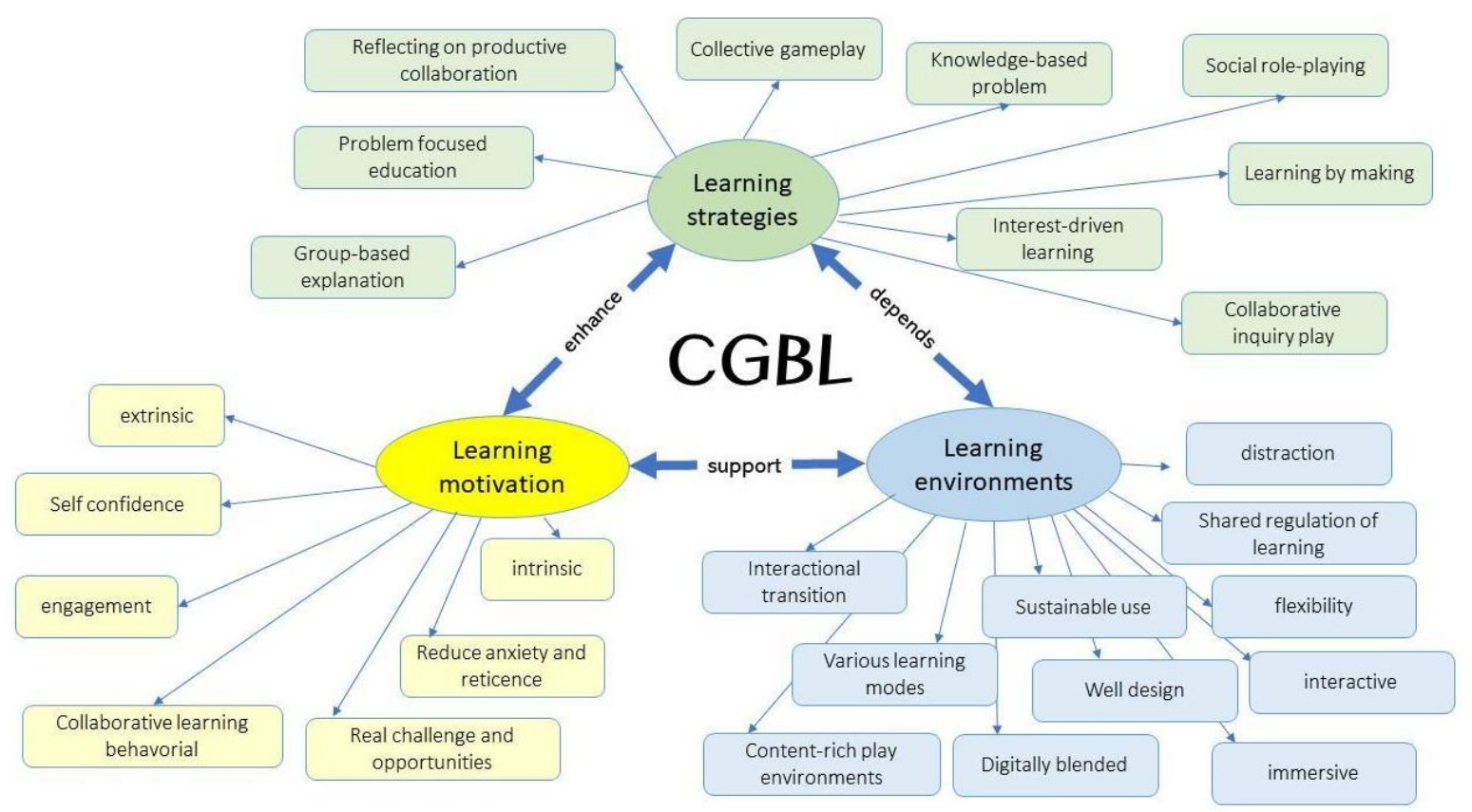

Figure 8. Themes and sub-themes for CGBL factors of effectiveness

\subsubsection{Learning Environment}

The diverse physical locations, contexts, and cultures in which students learn are referred to as the learning environment. Since students can learn in many settings, including natural settings and outside-of-school settings, the terminology is frequently used as a more realistic or preferred alternative to the classroom, which connotes a room with rows of desks and a chalkboard, for example. A school or class's culture is also included in this definition. Its guiding ethos and qualities include how people interact with and treat one another and how teachers structure a classroom to support learning.

This concept helps students to learn in many situations. Since students need to learn, the goal is to build a complete learning environment that optimises students' ability to learn. Unquestionably, there is no one optimal setting for learning. There are countless learning environments, which makes teaching so fascinating rather than a fixed learning environment. Formal learning occurs in the classroom and is organised for students to learn to fulfil course requirements. Informal learning can happen through reading and self-education, activities, interaction, or common activities (Cross, 2007; Selwyn, 2007). Attwell (2007), stated that in the workplace, studying colleagues, informal learning by asking questions, and other uncoordinated and autonomous learning practises accounted for $80 \%$ of an individual's awareness of their task. However, in terms of educational technology, slight attention has been paid to informal learning. Surprisingly, formal learning technology and applications have only been made available to those enrolled on an educational programme or those working for larger enterprises. Likewise, Hall (2009) suggested that formal and informal learning should be related to boosting learning and that when the learner participates in formal and informal learning activities, learning is most effective. 


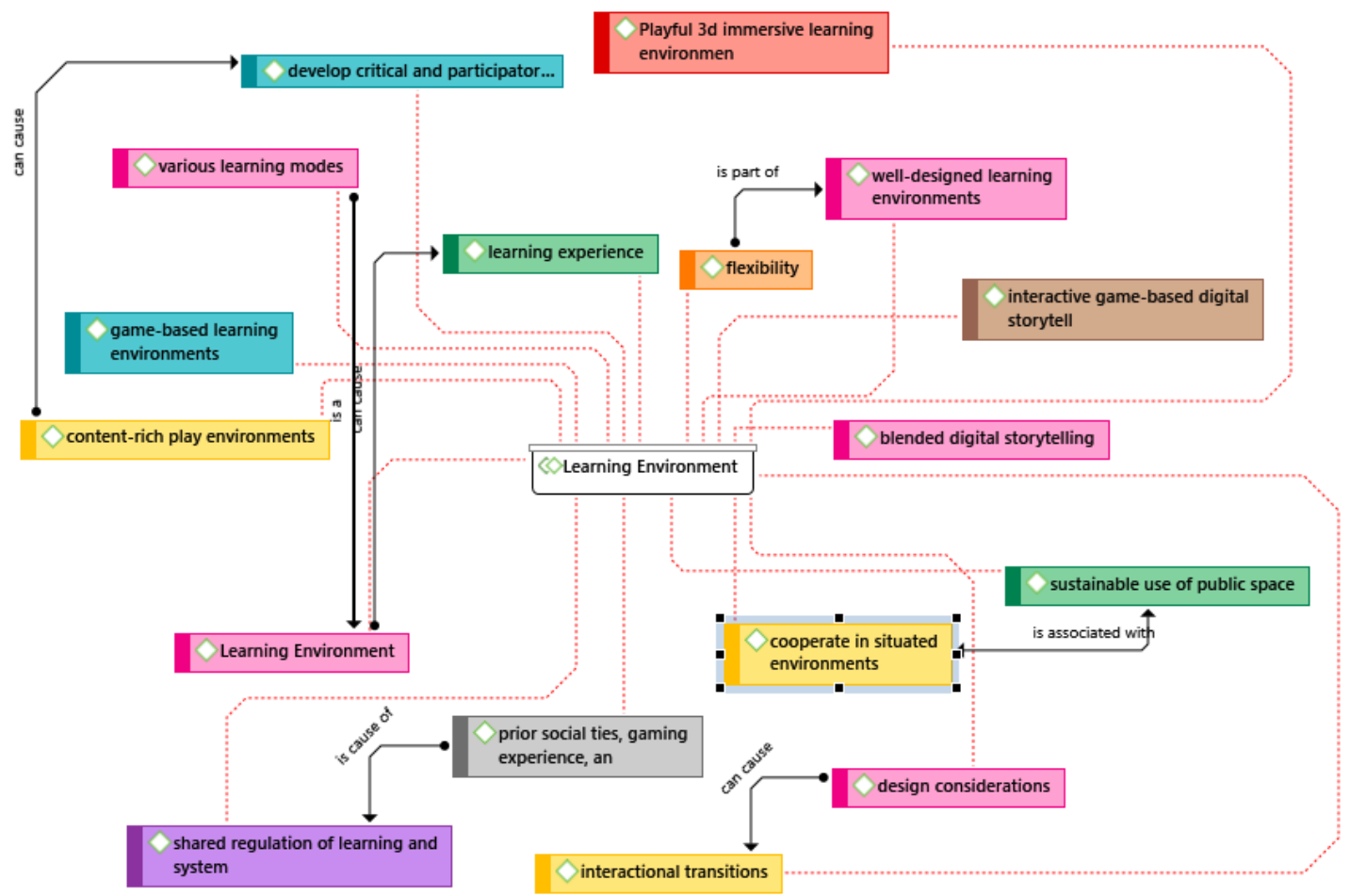

Figure 9. Learning Environment

Lauren et al. (2016) asserted that in carrying out DGBL, environmental activity is flexible to be a factor that contributes to the feasibility of learning activities. Meanwhile according to Cheng et al. (2019), the implementation of DGBL should emphasise the sustainable environment and be used anywhere. In contrast to these opinions (Shih \& Hsu, 2016), students should be co-competitive in a comfortable environment. Martin and Martinez (2016) indicated that in implementing games in the classroom and practice in the library, it was necessary to consider well-designed learning environments. Design consideration in activism and teacher instructional game building implementation are crucial $(\mathrm{Li}, 2018)$ as a theory adoption and design consideration investigation. Since teachers aim to make learning as effective as possible, they also aim to create an environment for learning that optimises the ability of students to learn. Learning environments have both a direct and indirect influence, or respectively positive and negative influence on learning. Therefore, teachers need to carefully choose or design it such as content-rich play environments (Saleh et al., 2019).

However, the pedagogical discussion is limited to only individual strategies in DGBL. Further research can be carried out to determine the effectiveness of DGBL in collaborative learning according to the different learning environments, i.e. formally and informally, which are appropriate with the current pandemic conditions that have forced students and teachers to carry out learning activities from home.

\subsubsection{Learning Motivation}

Due to the rapid advancement of computer and multimedia technologies (Hwang \& Wu, 2012), various issues of education computer games have been discussed extensively in recent years. Educational computer games, according to researchers, could be an effective technique to provide a more engaging learning environment for obtaining knowledge (Cagiltay, 2007; Papastergiou, 2009; Gunter et al., 2008a). Several studies have found that instructional computer games can improve students' motivation and interest in learning (Burguillo, 2010; Dickey, 2011; Ebner \& Holzinger, 2007; Harris \& Reid, 2005; Liu \& Chu, 2010). Hwang, Sung, Hung, Yang, and Huang (2012) have suggested that well-designed instructional computer games may have a significant impact on students' learning outcomes. 


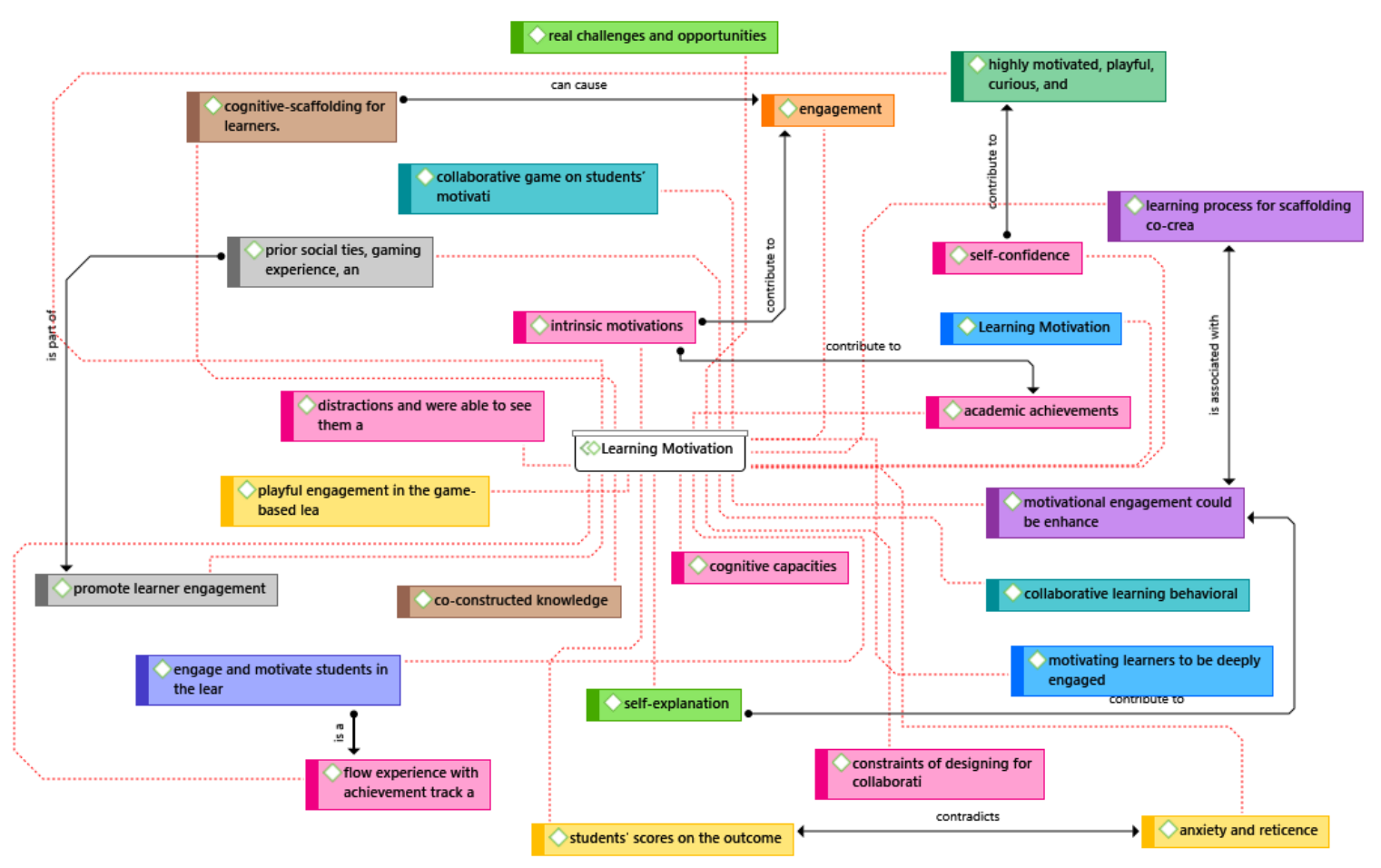

Figure 10. Learning Motivation

Although computer educational games appear to be a viable strategy, researchers have warned that DGBL techniques could have negative consequences if they are not properly designed, such as poor learning results and an increase in players' self-alienating behaviours (Hong et al., 2009; Sung et al., 2012; Provenzo, 1992). One of the most difficult aspects of producing educational computer games, according to Kickmeier-Rust and Albert (2010) is offering help and guidance to learners while balancing learning and gaming while also challenging individual learners' capacities. Charsky and Ressler (2011) used a computer game to conduct a learning activity, which further validated this conclusion. Students' collaborative efforts resulted in a higher level of achievement for all (Chen et al., 2020). Students develop a supportive community by assisting one another, which improves each member's performance. Students' motivation is increased when they have more control over their learning experiences through collaborative learning and play. Control, as previously established, is a powerful motivation. Cooperative learning emphasises students' active participation in the learning process (Yien et al., 2011). Collaborative learning in DGBL gives groups possession of their learning instead of passively accepting information from outside experts. Student empowerment created by the collaborative learning method leads to a positive attitude and increased motivation. It has been shown to develop positive student-teacher attitudes (Ho, 2020).

Besides, lines of communication are opened (Çelik, 2020b; Hung et al., 2017; Jesus et al., 2021; Asmalina Saleh et al., 2019b; Wang, 2020). Students are actively encouraged to explain their actions and thoughts to other students and their teachers. Their involvement increases and learning becomes more personal (Agatha \& Muhamad, 2016; Raman, 2015). In addition, according to van Putten et al., (2020), students had more focus when the content was being taught (learners engaged with teachers, asked questions, no evidence of distraction). They were motivated to start with the game-based assignments. Moreover, they had good engagement with peers (providing tips, collaboration, sharing understanding, asking questions, commitment in solving game problems). It is the part of students' enjoyment of working collaboratively (motivated to work with teammates, passion when the teacher introduced group work, revitalizing conversations).

Consequently, students are inclined to complete the game-based activity (active engagement with the game-based worksheet, engagement until the puzzle is solved). Students learn from peers (team members provide tips or reasons for answers, curiosity, and questions). As asserted by Chen et al. (2020), Cheng et al. (2019), and van Putten et al. (2020), although the group or team seemed to rely on each other for support during the learning process, they also tried to complete the work on their own. Based on the observation notes, the 
students seemed to pay attention to each other's comments but the will to implement them was absent. They were not always committed to solving the game problem together. However, when they needed help, they asked for it and learnt from each other, double-checking their responses to be sure they were correct. Furthermore, even though they were competing, learners from different teams were found to help each other. As a result, when using computer games in education, it is critical to provide appropriate learning support.

\subsubsection{Learning Strategies}

According to Code and Zap (2009), students employ learning strategies to aid them in the learning process. While Quarles et al. (2018) stated that learning strategies are ways to assist in learning. Nevertheless, learning strategies using digital technology (Gaines, 2021) refer to skills students use to understand different responsibilities and to choose and effectively employ the appropriate strategies to achieve or meet goals.

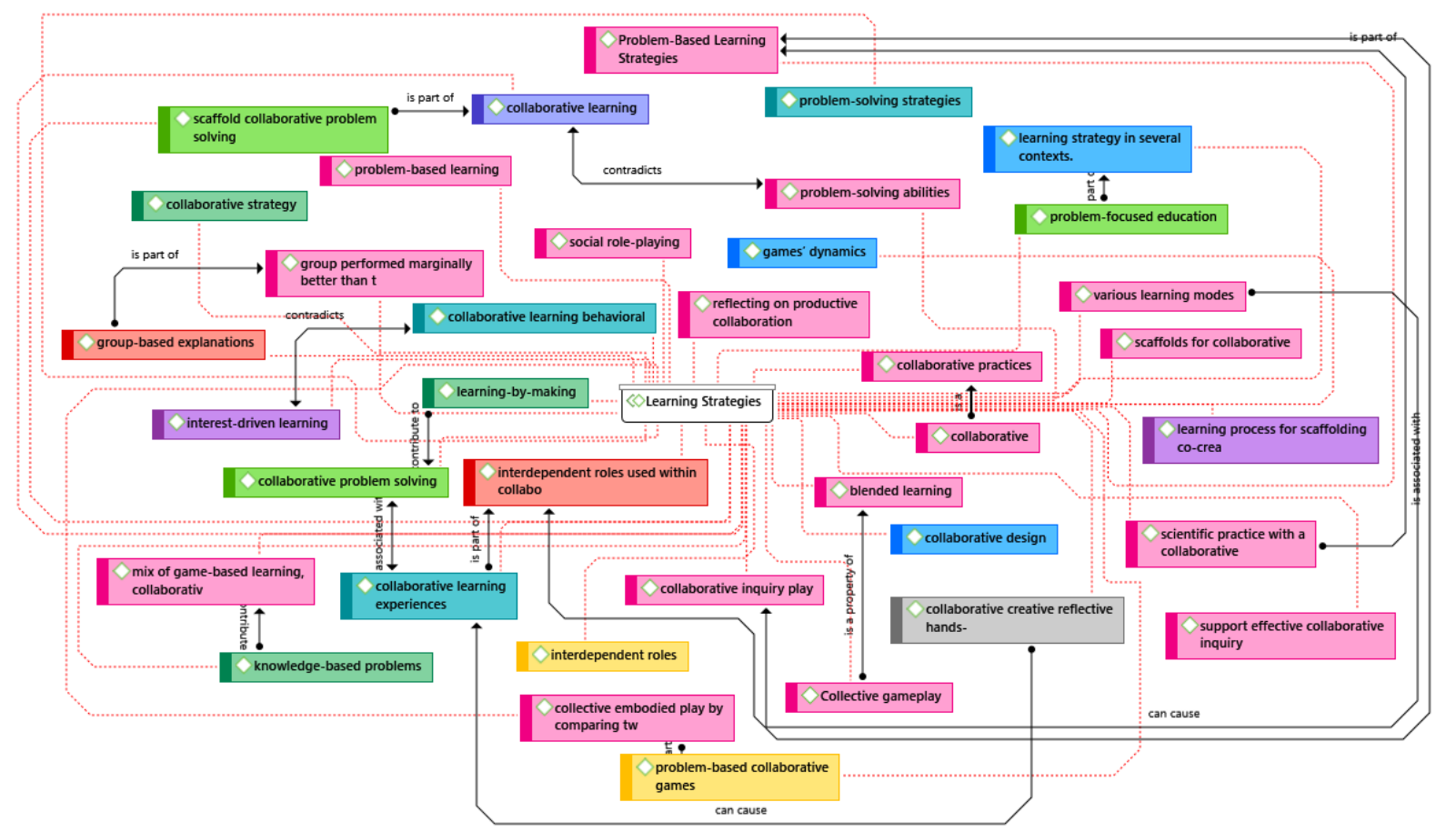

Figure 11. Learning Strategies

According to Hung et al. (2017), the findings showed that DGBL with multiplayer gameplay was successful in providing pupils with a variety of games. Each game had a varied difficulty level as well. During the game, players might consult their friends for information (the collaborative aspect) and then adjust their problem-solving strategies via a shared interface. In engaging middle school students in a scientific practice with a collaborative mobile game, Bressler, Bodzin, and Tutwiler (2019) used blended learning to investigate whether the players' flow experience differed by achievement track, gender, or gender structure working groups. In line with Cheng et al. (2019) and Liao et al. (2019), the study found that collaborative learning could increase students' intrinsic motivation in DGBL. Using blended learning strategies, students could experience various skills, knowledge, and different understanding types with different strategies. It increased collaborative skills, and students could reflect on productive outcomes. While applying group-based explanations, social role-playing was one of the strategies that could enhance collaborative learning behaviour. Interdependent roles were included in a collaborative mobile game to facilitate collaborative problem-solving and promote scientific practice (Bressler et al., 2019). Different strategies in several contexts also contribute to the effectiveness of DGBL in group learning settings, as strategies need to be structured according to students' circumstances and needs (Carpenter et al., 2020; Magno De Jesus \& Frango Silveira, 2020; Saleh et al., 2019; Sun, 2020). Various learning strategies, such as knowledge-based problems, interest-driven learning, social role-playing, collaborative problem-solving, and collaborative inquiry play, can effectively integrate CGBL.

\section{Discussion and Future Studies}

The Covid-19 pandemic is breaking out all over the world. In Malaysia, education is one of the sectors that are most affected by the Covid-19 outbreak. As a result, learning cannot be carried out face-to-face. Therefore, the Ministry of Education issued a policy for learning activities to be carried out from home. This new policy 
requires all elements of education to be immediately adapted to existing conditions. Although learning is carried out online, it must still follow the educational standards. The choice of learning model should consider the students' needs and include fun learning. A solution that can be applied to online learning during the pandemic is to implement DGBL. The implementation of DGBL can be carried out in CGBL. CGBL can foster learning motivation and student activity to be involved in learning. Besides, the application of game-based learning is able to improve student learning outcomes and creativity.

Based on the themes that were formed from the qualitative findings, three main factors contributed to the effectiveness of CGBL. The learning environment is a critical element in learning, with no exception in the digital environment. However, how can CGBL be included in the virtual learning environment of the current situation? The physical distance imposed by Covid-19 has influenced digital learning (Al-Emran, 2020). DGBL allows educators to customise their teaching tactics and enables students to self-regulate their learning without regard to time or place. Teachers must also devote time to studying how to use technological tools and comprehending how to improve their students' educational experiences. Every classroom is different and full of students with varying degrees of abilities. While this provides an enriching learning environment, it also presents challenges for teachers. Through DGBL, teachers use data to better understand students' needs to adjust tactics and personalise a student's learning experience. In addition, by providing students with CGBL, there is no back row-every student can see the lesson, which presents increased engagement, motivation, and learning. When students are involved in their education, they can be more engaged with the content, delivery, and understanding. Through DGBL, students make their avatars and earn and lose points based on behaviour, engagement, collaboration, and productivity. The interaction not only makes it more fun but also encourages students to uphold classroom values. Although this illustrates the positive effects of game-based learning, there would be great value in seeing how in-game behaviour translates to real-life behaviour in the long term. Although measuring the long-term impact is still on the wish list, researchers can gather quantitative data to evaluate the effects of CGBL.

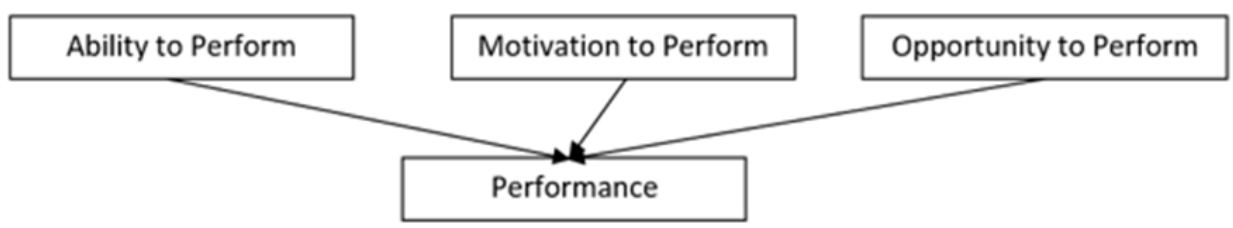

Figure 12. Ability, Motivation, Opportunity (AMO) model

Figure 12 is the AMO model adapted by (Ashford et al., 2014) derived from the AMO theory introduced by (Appelbaum et al., 2000). The results of this review are also in line with the ability, motivation and opportunity AMO model adapted from (Ashford et al., 2014) suggesting that three distinct work system components influence employee attributes and contribute to the company's success. According to the notion, a system that considers employees' skills, motivation, and opportunity best serves the organisation's objectives. When implemented in education, it is in line with how the learning environment, learning motivation, and learning strategies can contribute to performance to ensure the effectiveness of DGBL in applying CGBL in teaching and learning.

According to Ashford (2014), motivation is one of the most critical factors influencing individual efficiency. On the other hand, the AMO model emphasises motivation supported by relevant skills and abilities and appealing job opportunities. This implies that while motivation significantly impacts student performance, it has a minor impact on student attainment. The ability to perform can be associated with a learning environment that explains how the learning environment in CGBL provides opportunities for students to conduct DGBL in various environments. It provides an opportunity for students to experience varied learning environments, especially in virtual learning situations. Students gain a sense of connection, engagement, and well-being by participating in the decision-making process in a group discussion (Appelbaum et al., 2000). This statement refers to learning strategies, and students in CGBL could use a variety of learning strategies.

When moving towards greater integration of online learning environments, several questions have been asked about how students' motivation and learning strategies might impact their achievement in these environments and their preferences. According to Palloff and Pratt (2003), online learning might not match students' ideal learning style. According to Clayton et al. (2010), students want engaging learning environments that promote direct interaction with their professor and fellow students, immediate feedback, spontaneity, and contacts with faculty and students. Considering these criteria, conciseness of students' motivation and learning strategies will 
be possible form an effective learning environment for DGBL implementation.

This review paper highlights an approach as a guideline to educators, system developers, policymakers, academics, and stakeholders interested in integrating DGBL into the formal education system. The virtual collaborative strategy could eventually replace the traditional collaborative process. When applying DGBL in a collaborative learning environment, it is crucial to consider whether the games can support collaboration in a virtual learning environment. In addition, learning motivational factors are a significant factor in applying DGBL collaboratively. However, based on the analysis, it is still unclear how CGBL can improve student learning motivation in literature. In practically all aspects of CGBL, a shortage of studies discusses how CGBL can be carried out in the pandemic era. Therefore, this issue should be further delved into to understand how to use DGBL more effectively in the future.

\section{Conclusion}

Systematic Thematic Review synthesised literature from 2016 until 2021 on CGBL in the digital environment aspects related to CGBL effectiveness. However, there is a shortage of insight into what factors support DGBL's efficiency in a digital environment when applying CGBL in the education system. The results from the thematic review are the themes that exist as a result of the literature highlights. The themes that emerge are the learning environment, learning motivation, and learning strategies, which contribute to the effectiveness of CGBL. These themes are in line with the AMO model introduced by Ashford (2014). This paper provides insight into subsequent research as a guideline to educators, system developers, policymakers, academics, and stakeholders interested in considering the implementation of CGBL in Teaching and Learning at Home as one of the appropriate alternative materials and methods in the new standard on the factors reviewed. There are a few limitations to this study that should be considered when replicating it in the future. First, there is little knowledge of the best practice to integrate CGBL in different learning strategies and learning environments. While this study did not examine aspects of the game itself, future research is needed to explore the extent to which game characteristics concerning students' participation in DGBL are related to their learning outcomes. It would also be useful to conduct painstaking studies on the structure and presentational styles of CGBL and how they interrelate with other instructional contexts, as this would enable detailed study.

\section{Acknowledgements}

We are grateful for the funding given to us by the University Research Management Centre for this "Putra Future Classroom-Ingeniworks Game Initiative: Community Building Through Health-Based Game for Future Learners and Young Malaysians" university-industry matching grant research project (UPM/ 800-3/3/1/Matching - Geran Putra/2018/9300441).

\section{References}

Agatha, F. U., \& Muhamad, S. T. (2016). Faktor-faktor yang mempengaruhi e-pembelajaran dalam kalangan pelajar di Institut. Jurnal Penyelidikan IPGKBL, 13, 1-14.

Ahmad, A. (2017). Industri 4.0 ubah cara kerja, hidup. Berita Harian Online.

Al-Emran, M. (2020). Mobile learning during the era of COVID-19.

Appelbaum, E., Bailey, T., Berg, P., \& Kalleberg, A. (2000). Manufacturing competitive advantage: The effects of high performance work systems on plant performance and company outcomes. Cornell University Press.

Ashford, S. J., Blatt, R., \& VandeWalle, D. (2014). Reflections on the looking glass: A review of research on feedback-seeking behavior organizations. Journal of Management, 29(6), 773-799. https://doi.org/10.1016/S0149-2063(03)00079-5

Attwell, G. (2007). Personal Learning Environments - the future of eLearning ? Lifelong Learning, 2(January), 1-8. http://www.elearningeuropa.info/files/media/media11561.pdf

Bahrom, Z. (2013). Pedagogi Norma Baharu: Cabaran dan Hikmah. Journal of Chemical Information and Modeling, 53(9), 1689-1699.

Bartolomé, A., Castañeda, L., \& Adell, J. (2018). Personalisation in educational technology: The absence of underlying pedagogies. International Journal of Educational Technology in Higher Education, 15(1). https://doi.org/10.1186/s41239-018-0095-0

Bressler, D. M., Bodzin, A. M., \& Tutwiler, M. S. (2019). Engaging middle school students in scientific practice with a collaborative mobile game. Journal of Computer Assisted Learning, 35(2), 197-207. https://doi.org/10.1111/jcal.12321 
Bressler, D. M., Bodzin, A. M., Eagan, B., \& Tabatabai, S. (2019). Using Epistemic Network Analysis to Examine Discourse and Scientific Practice During a Collaborative Game. Journal of Science Education and Technology, 28(5), 553-566. https://doi.org/10.1007/s10956-019-09786-8

Bughin, J., Hazan, E., Lund, S., Dahlstrom, P., Wiesinger, A., \& Subramaniam, A. (2018). Skill shift: Automation and the future of the workforce. McKinsey Global Institute: San Francisco

Burguillo, J. C. (2010). Using game theory and Competition-based Learning to stimulate student motivation and performance. Computers and Education, 55(2), 566-575. https://doi.org/10.1016/j.compedu.2010.02.018

Cagiltay, N. E. (2007). Teaching software engineering by means of computer-game development: Challenges and opportunities. British Journal of Educational Technology, 38(3), 405-415. https://doi.org/10.1111/j.1467-8535.2007.00705.x

Campos, I. (2018). Digital Games to Teach News Literacy to Children. In Proceedings of Play2Learn 2018, 195-212

Carpenter, D., Emerson, A., Mott, B. W., Saleh, A., Glazewski, K. D., Hmelo-Silver, C. E., \& Lester, J. C. (2020). Detecting off-task behavior from student dialogue in game-based collaborative learning. Lecture Notes in Computer Science (Including Subseries Lecture Notes in Artificial Intelligence and Lecture Notes in Bioinformatics). https://doi.org/10.1007/978-3-030-52237-7_5

Charsky, D., \& Ressler, W. (2011). "Games are made for fun": Lessons on the effects of concept maps in the classroom use of computer games. Computers and Education, 56(3), 604-615. https://doi.org/10.1016/j.compedu.2010.10.001

Chen, S., Jamiatul Husnaini, S., \& Chen, J.-J. (2020). Effects of games on students' emotions of learning science and achievement in chemistry. International Journal of Science Education, 42(13), 2224-2245. https://doi.org/10.1080/09500693.2020.1817607

Cheng, Y.-W., Wang, Y., Cheng, I.-L., \& Chen, N.-S. (2019). An in-depth analysis of the interaction transitions in a collaborative Augmented Reality-based mathematic game. Interactive Learning Environments, 27(5-6), 782-796. https://doi.org/10.1080/10494820.2019.1610448

Clarke, V., \& Braun, V. (2013). Teaching thematic analysis: Overcoming challenges and developing strategies for effective learning Associate Professor in Sexuality Studies Department of Psychology Faculty of Health and Life Sciences University of the West of England Coldharbour Lane Br. University of the West of England, 26, 120-123.

Clayton, K., Blumberg, F., \& Auld, D. P. (2010). The relationship between motivation, learning strategies and choice of environment whether traditional or including an online component. British Journal of Educational Technology, 41(3), 349-364. https://doi.org/10.1111/j.1467-8535.2009.00993.x

Cope, B., \& Kalantzis, M. (2010). Ubiquitous learning. Ubiquitous Learning, 12(4), 1-279. https://doi.org/10.4324/9781315639215-2

Dickey, M. D. (2011). Murder on Grimm Isle: The impact of game narrative design in an educational game-based learning environment. British Journal of Educational Technology, 42(3), 456-469. https://doi.org/10.1111/j.1467-8535.2009.01032.x

Ebner, M., \& Holzinger, A. (2007). Successful implementation of user-centered game based learning in higher education: An example from civil engineering. Computers and Education, 49(3), 873-890. https://doi.org/10.1016/j.compedu.2005.11.026

Gunter, G. A., Kenny, R. F., \& Vick, E. H. (2008). Taking educational games seriously: Using the RETAIN model to design endogenous fantasy into standalone educational games. Educational Technology Research and Development, 56(5), 511-537. https://doi.org/10.1007/s11423-007-9073-2

Harris, K., \& Reid, D. (2005). The Influence of Virtual Reality Play on Children'S Motivation. Canadian Journal of Occupational Therapy, 72(1), 21-29. https://doi.org/10.1177/000841740507200107

Ho, J. (2020). Gamifying the flipped classroom: How to motivate Chinese ESL learners? Innovation in Language Learning and Teaching, 14(5), 421-435. https://doi.org/10.1080/17501229.2019.1614185

Hong, J. C., Cheng, C. L., Hwang, M. Y., Lee, C. K., \& Chang, H. Y. (2009). Assessing the educational values of digital games. Journal of Computer Assisted Learning, 25(5), 423-437. https://doi.org/10.1111/j.1365-2729.2009.00319.x 
Huang, R., Yang, J., \& Chang, T.-W. (2020). Handbook on Facilitating Flexible Learning During Educational Disruption: The Chinese Experience in Maintaining Undisrupted Learning in COVID-19 Outbreak 15 Mac 2020. International Research and Training Center for Rural Education, March, 1-48. Retrieved from https://www.researchgate.net/publication/339939064

Hung, C.-Y., Lin, Y.-R., Huang, K.-Y., Yu, P.-T., \& Sun, J. C.-Y. (2017). Collaborative game-based learning with motion-sensing technology: Analyzing students' motivation, attention, and relaxation levels. International Journal of Online Pedagogy and Course Design, 7(4), 53-64. https://doi.org/10.4018/IJOPCD.2017100104

Hussin, N. (2017). Penggunaan Laman Web Sebagai Transformasi Dalam Pengajaran Dan Pembelajaran Pendidikan Islam. O-JIE: Online Journal of Islamic Education, 1(2). Retrieved from https://ojie.um.edu.my/article/view/5534

Hwang, G. J., \& Wu, P. H. (2012). Advancements and trends in digital game-based learning research: A review of publications in selected journals from 2001 to 2010. British Journal of Educational Technology, 43(1), 6-10. https://doi.org/10.1111/j.1467-8535.2011.01242.x

Islam, R. (2017). Deep reinforcement learning technologies. ArXiv, 3207-3214.

Keskitalo, T., Pyykkö, E., Ruokamo, H., Keskitalo, T., Pyykkö, E., \& Ruokamo, H. (2016). International Forum of Educational Technology \& Society Exploring the Meaningful Learning of Students in Second Life. Published by : International Forum of Educational Technology \& Society Linked references are available on JSTOR for this article. Explori. 14(1), 16-26.

Kickmeier-Rust, M. D., \& Albert, D. (2010). Micro-adaptivity: Protecting immersion in didactically adaptive digital educational games. Journal of Computer Assisted Learning, 26(2), 95-105. https://doi.org/10.1111/j.1365-2729.2009.00332.x

Lauren, H., Lutz, C., Wallon, R. C., \& Hug, B. (2016). Integrating the dimensions of NGSS within a collaborative board game about honey bees. American Biology Teacher, 78(9), 755-763. https://doi.org/10.1525/abt.2016.78.9.755

Li, Q. (2018). Enactivism and teacher instructional game building: An inquiry of theory adoption and design consideration. Educational Technology Research and Development, 66(6), 1339-1358. https://doi.org/10.1007/s11423-018-9584-z

Liao, C.-W., Chen, C.-H., \& Shih, S.-J. (2019). The interactivity of video and collaboration for learning achievement, intrinsic motivation, cognitive load, and behavior patterns in a digital game-based learning environment. Computers and Education, 133, 43-55. https://doi.org/10.1016/j.compedu.2019.01.013

Liu, T. Y., \& Chu, Y. L. (2010). Using ubiquitous games in an English listening and speaking course: Impact on learning outcomes and motivation. Computers and Education, 55(2), 630-643. https://doi.org/10.1016/j.compedu.2010.02.023

Magno De Jesus, A., \& Frango Silveira, I. (2020). Game-based collaborative learning framework for computational thinking development. Revista Facultad de Ingeniería Universidad de Antioquia. https://doi.org/10.17533/udea.redin.20200690

Martin, C., \& Martinez, R. (2016). Games in classroom and practice in library and information science education. On the Horizon, 24(1), 82-87. https://doi.org/10.1108/OTH-08-2015-0051

Mat Dawi, A. H., Lee Siong, T., Mohan, P., \& Dolah, J. (2016). PENERIMAAN ALAT WEB 2.0 DALAM PELAKSANAAN KURIKULUM PROGRAM BERASASKAN PEMBELAJARAN ABAD KE-21 DI INSTITUT PENDIDIKAN GURU (pp. 32-50).

Mitchell, A., \& Savill-Smith, C. (2004). The use of computer and video games for learning: A review of the Literature, Learning and Skills Development Agency. In A review of the literature. Retrieved from http://www.isda.org.uk/files/PDF/1529.pdf

Murray, M. C., \& Pérez, J. (2015). Informing and performing: A study comparing adaptive learning to traditional learning. Informing Science, 18(1), 111-125. https://doi.org/10.28945/2165

Palloff, R. M., \& Pratt, K. (2003). The virtual student: A profile and guide to working with online learners. San Francisco: Jossey-Bass.

Papastergiou, M. (2009). Digital Game-Based Learning in high school Computer Science education: Impact on educational effectiveness and student motivation. Computers and Education. https://doi.org/10.1016/j.compedu.2008.06.004 
Prasetyo, H., \& Sutopo, W. (2018). INDUSTRI 4.0: TELAAH KLASIFIKASI ASPEK DAN ARAH PERKEMBANGAN RISET. J@ti Undip : Jurnal Teknik Industri. https://doi.org/10.14710/jati.13.1.17-26

Prensky, M. (2007). Digital Game-Based Learning. Paragon House. Retrieved from https://books.google.com.my/books?id=e-CjQAAACAAJ

Raman, J. (2015). Mobile technology in nursing education: WHERE do we go from here? A review of the literature. Nurse Education Today, 35(5), 663-672. https://doi.org/10.1016/j.nedt.2015.01.018

Saleh, A., Hmelo-Silver, C. E., Glazewski, K. D., Mott, B., Chen, Y., Rowe, J. P., \& Lester, J. C. (2019). Collaborative inquiry play: A design case to frame integration of collaborative problem solving with story-centric games. Information and Learning Science, 120(9-10), 547-566. https://doi.org/10.1108/ILS-03-2019-0024

Selwyn, N. (2007). “Screw blackboarddotsdo it on Facebook!': An investigation of students' educational use of Facebook (pp. 1-23).

Shih, J.-L., \& Hsu, Y.-J. (2016). Advancing adventure education using digital motion-sensing games. Educational Technology and Society, 19(4), 178-189. Retrieved from https://www.scopus.com/inward/record.uri?eid=2-s2.0-85000869962\&partnerID=40\&md5=bb0f20ed8634e 1078a9b2aac00b2ab24

Sun, C. (2020). Collaborative problem solving in triads and its influence on performance in a game-based learning environment. Orphanet Journal of Rare Diseases.

Sung, H. Y., Hwang, G. J., Hung, C. M., \& Huang, I. W. (2012). Effect of learning styles on students' motivation and learning achievement in digital game-based learning. Proceedings of the 2012 IIAI International Conference on Advanced Applied Informatics, IIAIAAI 2012, 258-262. https://doi.org/10.1109/IIAI-AAI.2012.59

Sutton, M. J., \& Jorge, C. F. B. (2020). Potential for radical change in Higher Education learning spaces after the pandemic. Journal of Applied Learning and Teaching, 3(1). https://doi.org/10.37074/jalt.2020.3.1.20

van Putten, S., Blom, N., \& van Coller, A. (2020). The developmental influence of collaborative games in the Grade 6 mathematics classroom. International Journal of Mathematical Education in Science and Technology, O(0), 1-24. https://doi.org/10.1080/0020739X.2020.1829139

Wibawa, S. (2018). Pendidikan dalam Era Revolusi Industri 4.0. Academia.Edu, 8(2), 1-10.

Wouters, P., \& Van Oostendorp, H. (2013). A meta-analytic review of the role of instructional support in game-based learning. Computers and Education, 60(1), 412-425. https://doi.org/10.1016/j.compedu.2012.07.018

Yien, J. M., Hung, C. M., Hwang, G. J., \& Lin, Y. C. (2011). A game-based learning approach to improving students' learning achievements in a nutrition course. Turkish Online Journal of Educational Technology, $10(2), 1-10$.

Zairul, M. (2020). A Thematic Review on Student-Centred Learning in the Studio Education. Journal of Critical Reviews, 7(2), 504-511. https://doi.org/10.31838/jcr.07.02.95

Zhou, L., \& Li, F. (2020). A Review of the Largest Online Teaching in China for Elementary and Middle School Students during the COVID-19 Pandemic. Best Evidence of Chinese Education, 5, 549-567. https://doi.org/10.15354/bece.20.re040

\section{Copyrights}

Copyright for this article is retained by the author(s), with first publication rights granted to the journal.

This is an open-access article distributed under the terms and conditions of the Creative Commons Attribution license (http://creativecommons.org/licenses/by/4.0/). 